\title{
Analysis of the freezing point of milk by precision method and by Fourier Transform Infrared (FTIR) spectroscopy
}

[Análise do ponto de congelamento do leite pelo método de precisão e por espectroscopia no infravermelho por transformada de Fourier (FTIR)]

\author{
R.F. Brito ${ }^{1}$, R. Rodrigues ${ }^{2}$, S.A. Diniz ${ }^{3}$, L.M. Fonseca ${ }^{2}$, M.O. Leite $^{2}$, M.R. Souza ${ }^{2}$, \\ R.S. Conrrado ${ }^{2}$, S.A.O. Veríssimo ${ }^{1}$, G.L.C. Valente ${ }^{1}$, M.M.O.P. Cerqueira ${ }^{2}$
}

\author{
${ }^{1}$ Aluno de pós-graduação - Escola de Veterinária - Universidade Federal de Minas Gerais - Belo Horizonte, MG \\ ${ }^{2}$ Escola de Veterinária - Universidade Federal de Minas Gerais - Belo Horizonte, MG \\ ${ }^{3}$ Centro Universitário Doctum - Teófilo Otoni, MG
}

\begin{abstract}
A total of 480 milk samples were analyzed in four repetitions with four preservative treatments (no preservative, Bronopol, Bronolat and Brononata), three storage times at temperatures up to $4{ }^{\circ} \mathrm{C}(24,48$ and 72hours after reception), five different water additions $(0.0,2.5,5.0,7.5$ and $10.0 \%)$ and two analytical instruments (electronic cryoscope and FTIR). The objective of this study was to evaluate the effect of these parameters in the determination of the freezing point by the reference method and by Fourier transform infrared spectroscopy, thus determining the best analytical conditions and establishing a mathematical equation for electronic determination by FTIR spectroscopy. Bronolat was the best preservative and Brononata was the worst and is not recommended to analyze freezing point by FTIR. The storage time of the samples did not interfere in the analytical determinations by the precision method and by FTIR.
\end{abstract}

Keywords: freezing point, raw milk, preservatives, electronic cryoscope, FTIR

\section{RESUMO}

Foram analisadas 480 amostras de leite em quatro repetições em relação a quatro tratamentos por conservantes (sem conservante, bronopol, bronolat e brononata), três tempos de armazenamento, em temperatura até $4^{\circ} \mathrm{C}$ desde a recepção da amostra (24, 48 e 72 horas), cinco porcentagens de adição de água (0,0; 2,5; 5,0; 7,5 e $10,0 \%$ ) e dois instrumentos analíticos (crioscópio eletrônico e FTIR). O objetivo foi avaliar o efeito desses parâmetros na determinação do índice crioscópico pelo método de precisão em crioscópio eletrônico e por espectroscopia com transformada de Fourier no infravermelho, determinando-se, assim, as melhores condições analiticas. Entre os conservantes utilizados, bronolat foi o melhor e brononata foi o menos eficiente, não sendo, portanto, recomendado para análise de crioscopia por FTIR. O tempo de armazenamento das amostras não interferiu nas determinações analíticas pelo método de precisão e por FTIR.

Palavras-chave: ponto de congelamento, leite cru, conservantes, crioscópio eletrônico, FTIR

\section{INTRODUCTION}

Milk is a natural and highly nutritious food, source of proteins, fat, vitamins and minerals, such as calcium, which is especially important in the nutrition of women and children, being also a product consumed daily and therefore of great economic importance. Despite this, adulterations sometimes occur in order to obtain financial advantages or hide undesirable characteristics to attain the acceptance of the product or increase the volume and solid contents (Rezende et al., 2015).

These adulterations constitute fraud, since raw milk must have the original composition, and the removal of components, or the addition of any substances to raw milk is illegal. The most common fraud known is adding water to increase the volume of raw milk and consequently the amount paid for it. This type of fraud leads to a

Recebido em 21 de março de 2020

Aceito em 1 de junho de 2020

E-mail: rommelf@hotmail.com 
reduction in the nutritional value of milk, the insertion of potentially hazardous substances, deception and financial loss to the consumer, public health risk, illegal competition and commercial disloyalty. Therefore, the identification of possible addition of water to milk, whether accidentally or fraudulently, is important. For the detection of added water to milk it is officially applied the freezing point analysis by the electronic cryoscope, which has a long analysis time, making it difficult to analyze large quantities of milk samples.

To increase the analytical capacity, the official milk quality analysis laboratories use medium infrared analyzers with FTIR (Fourier Transform Infrared) technology. These devices analyze a large number of samples more quickly, efficiently and at low cost due to the multiplicity of analyzes in a single device (Oliveira, 2011).

Due to the large amount of samples from distant regions and the time elapsed from collection to sample delivery, it is necessary to add a specific preservative to prevent deterioration of the product during transport and storage in a cold room, which could affect the result of the analysis. The addition of exogenous substances to milk, such as preservatives, can influence the results of the analyzes.

Thus, it is important that these effects are analyzed before implementing any sample conservation practice in a calibration scheme (Zajác et al., 2016). The objective of this work was to evaluate the effect of three preservatives, the time elapsed until the moment of the analysis and the addition of water in the determination of the freezing point of milk by the precision method in electronic cryoscope and by Fourier-transform Infrared spectroscopy, and with that, establish the best analytical conditions for using this equipment to determine the freezing point of milk in official milk quality assessment laboratories.

\section{MATERIAL AND METHODS}

Three Bronopol-based preservatives (2-bromo-2nitro-1, 3-propanediol) with the following trade names, Bronopol, Bronolat and Brononata, were used in this work. The preservatives were supplied by Embalpharma (Pescaria Brava, SC, Brazil), as well as their respective tubes and the empty tubes used for "preservative-free" treatment. The milk used in this work was collected according to Standard IDF 50C: 1995 (Milk..., 1995) in cooling tanks on rural properties in Minas Gerais, from September to November 2018, kept under refrigeration until delivery to the Laboratório de Análise da Qualidade do Leite da Escola de Veterinária da UFMG (LabUFMG), and then stored in the cold room $\left(4{ }^{\circ} \mathrm{C}\right)$.

The milk samples were divided in five treatments with different percentages of water addition $(0 \%$; $2.5 \% ; 5 \% ; 7.5 \% ; 10.0 \%$ ) and then poured into tubes with each preservative treatment (without preservative, Bronopol, Bronolat and Brononata) for three cold storage times at $4{ }^{\circ} \mathrm{C}$ until the time of analysis (up to $24 \mathrm{~h}$, up to $48 \mathrm{~h}$ and up to $72 \mathrm{~h}$ after reception) destined for the electronic cryoscope analysis and the FTIR analysis. Figure 1 illustrates the procedures from the moment the milk is received to the analysis.

The cryoscope calibration solutions were \begin{tabular}{l|l|ll} 
prepared according to ISO 5764 & IDF 108
\end{tabular} (International..., 2009a). The electronic cryoscope LK-7000 (Londrina, Paraná, Brazil) was calibrated daily according to the instructions in its manual and ISO 5764 | IDF 108 (International..., 2009a). Before the analysis, the sample was homogenized manually by pouring the tube at least 10 times.

Flow cytometry coupled to mid-infrared spectrometry with Fourier transform was performed using the CombiScope FTIR 400® (Delta Instruments; Drachten, Netherlands). The equipment was calibrated and checked daily following the instructions in the equipment manual, the LabUFMG Work Instructions and ISO 8196-1 | IDF 128 (International..., 2009b; International..., 2009c).

Standard calibration solutions are purchased from LANAGRO (Laboratórios Nacionais Agropecuários, MG, Brazil) for somatic cell count (SCC), Eurofins DQCI (Dairy Quality Control Incorporated, United States) for freezing point and Valacta (Dairy Production Center of Expertise, Quebec, Canada) for composition, casein and milk urea nitrogen (MUN). The freezing point and composition were determined automatically by the automatic composition analyzer based on medium infrared and the SCC of milk by flow cytometry. 
The equipment was calibrated for the analysis of SCC, milk composition (fat, protein, lactose, total solids, casein), freezing point and MUN according to the quality documentation of LabUFMG.
The statistical analysis of comparison between the methods was performed by calculating the confidence interval with $95 \%$ reliability, using the InfoStat software version 2008 (Di Rienzo et al., 2008).

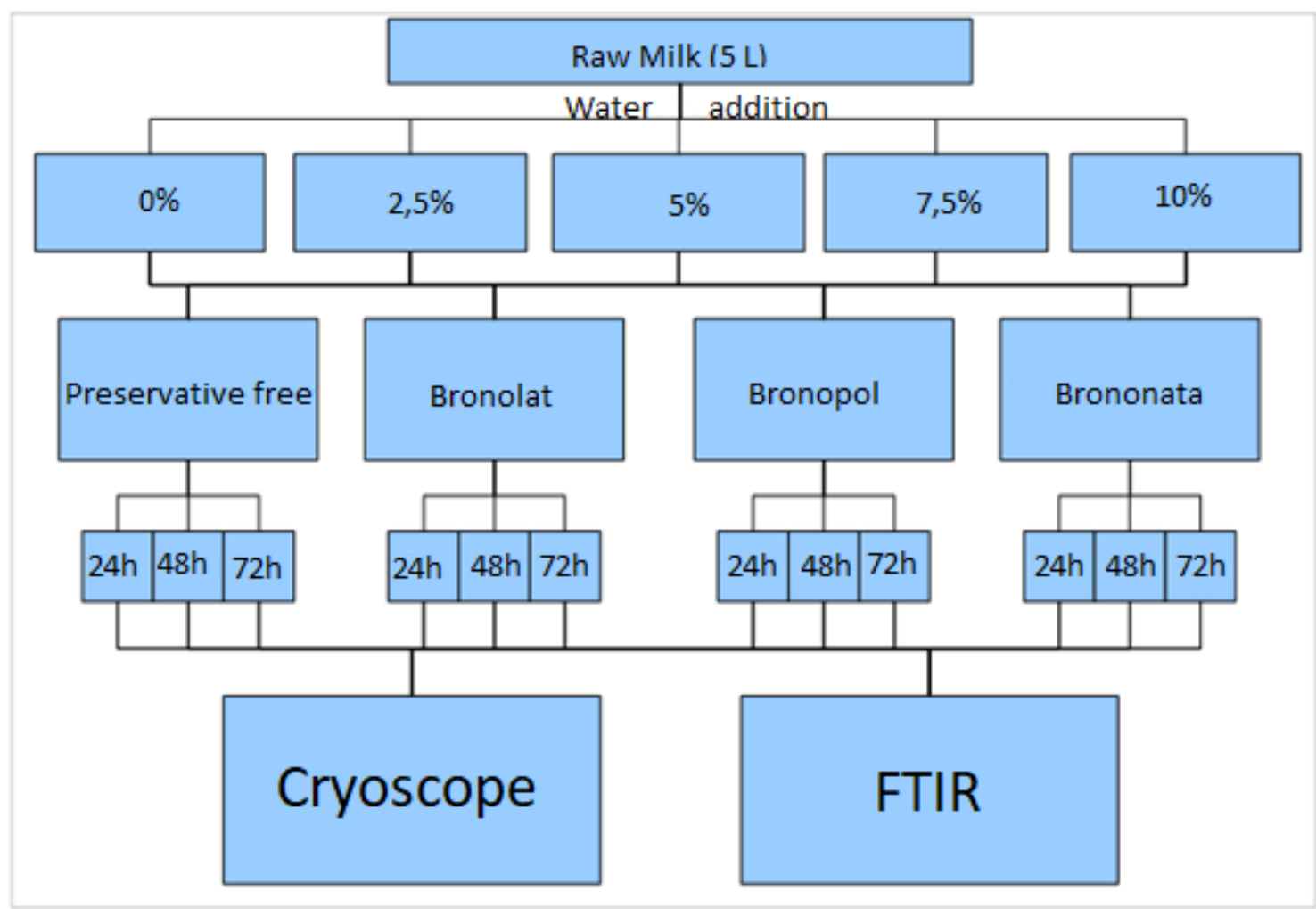

Figure 1. Schematic design of the experiment to evaluate the freezing point of milk under different conditions (water addition, preservation, storage time and analytical methods).

\section{RESULTS AND DISCUSSION}

The raw milk composition (fat, protein, lactose and total solids) showed results above the minimum values allowed by the legislation with up to $5 \%$ of water addition and for each of these parameters separately with up to $10 \%$ of water addition. These results reinforce the need to check the freezing point efficiently, because even when milk has normal component values, fraud by adding water can occur. Further research is needed to correlate the composition of the milk and the freezing point following the parameters of this study in order to verify whether any of the milk solids influence the freezing point result when analyzed by the FTIR, since the equipment uses the fat, protein and lactose contents to calculate the freezing point.

The results obtained by comparing milk analysis methods using tubes without preservative, with Bronopol and with Bronolat were not significantly different $(\mathrm{P}>0.05)$ for the freezing point by the Reference Method (electronic cryoscope) and by FTIR. This indicates that it is possible to store the milk samples with these three treatments in a cold chamber for up to three days after delivery in the analysis laboratories without affecting the reliability of the result for the freezing point (Figure 2). 

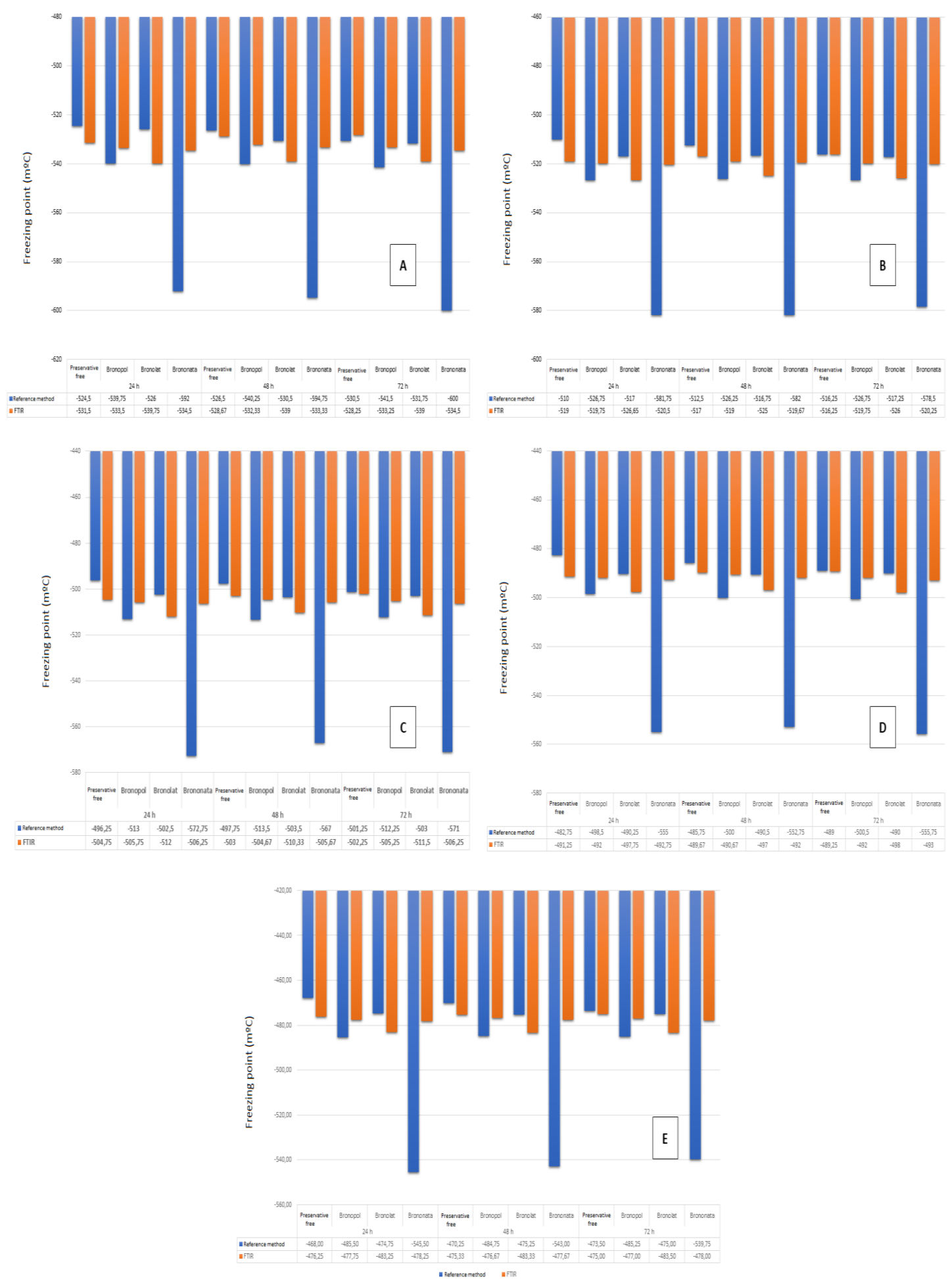

Figure 2. Freezing point of raw milk $\left(-\mathrm{m}^{\circ} \mathrm{C}\right)$ by two methodologies (Reference Method in blue and FTIR in orange) in four different preservative treatments (preservative free, Bronopol, Bronolat and Brononata) and three storage times $(24,48$ and $72 \mathrm{~h})$ for five water addition treatments: A. without adding water; B. $2.5 \%$ water addition; C. $5.0 \%$ water addition; D. $7.5 \%$ water addition; and E. $10.0 \%$ water addition. 
However, a significant difference was observed when the preservative Brononata was used, in all storage times $(\mathrm{P} \leq 0.05)$. Therefore, the use of this preservative for the determination of milk freezing point by FTIR analysis is not recommended, since there are different results when compared with analysis by the reference method (Figure 2).

Within the same storage time and method used, the Bronolat preservative was the most stable when compared to the result of samples without preservative, within all the different percentages of water addition $(\mathrm{P} \leq 0.05)$, being significantly different only in the $48 \mathrm{~h}$ time for the $10 \%$ of water addition treatment. The freezing point of milk preserved with Bronopol showed variable results when compared to samples without preservative in the $48 \mathrm{~h}$ time, the same occurred for the Brononata in the three analyzed times (24, 48 and 72h).

With the addition of $2.5 ; 5.0 ; 7.5$ and $10.0 \%$ water, the freezing point of milk from samples with Bronopol and Brononata were different $(\mathrm{P}>0.05)$ from the results obtained from samples without preservatives, at all times, showing interference in the analytical determination by the reference method. On the other hand, the results obtained by the FTIR method did not differ between Bronopol and Bronolat $(\mathrm{P}>0.05)$, which is a cause for concern because we detected interference of this preservatives on the Reference Method.

When comparing the freezing point averages ($\mathrm{m}^{\circ} \mathrm{C}$ ) by the Tukey test, no significant differences were observed $(\mathrm{P}>0.05)$ for preservative treatments by the FTIR, in any of the different storage times and water additions (Figure 2). Regarding the equipment used to measure the freezing point (electronic cryoscope and FTIR), as previously mentioned, the treatment with the Brononata preservative was the only one to obtain significantly different results among them for all three storage times and the five treatments of water additions (Figure 2).

\section{CONCLUSIONS}

Bronolat was the best preservative used to analyze the freezing point of milk by FTIR because it does not interfere with the readings obtained by the Reference Method at different storage times with and without the addition of water, except in an experimental condition ( $10 \%$ of water addition in up to $48 \mathrm{~h}$ by the Reference Method), proving to be the most stable preservative for measuring the freezing point. Brononata was the worst preservative for interfering in the determination of the freezing point of milk by the Reference Method and presenting a significant difference for the freezing point between methods for all storage times and conditions (without and with the addition of water) tested. Bronopol showed interference in the determination of the freezing point of milk by the Reference Method in various storage times and conditions (without and with the addition of water). Samples chemically preserved with the Bronolat preservative and stored up to $4^{\circ} \mathrm{C}$ from the moment of reception can be analyzed within $72 \mathrm{~h}$ without significant changes in the freezing point result by FTIR and by the reference method. In addition, it is recommended to carry out periodic analyzes of milk without preservative and with the preservative used by RBQL laboratories using reference methods and FTIR to avoid possible interference with analytical results.

\section{REFERENCES}

DI RIENZO, J.; CASANOVES, F.; BALZARINI, M. et al. InfoStat - Statistical Software Version 2008. Available in: http://www.infostat.com.ar/. Accessed in: 9 Jan. 2019.

INTERNATIONAL Standard - ISO 5764|IDF 108. Milk - determination of freezing point thermistor cryoscope method (Reference method). 2009a.

INTERNATIONAL Standard - ISO 8196|IDF 128-1. Milk - definition and evaluation of the overall accuracy of alternative methods of milk analysis - part 1: analytical attributes of alternative methods. $2009 \mathrm{~b}$.

INTERNATIONAL Standard - ISO 8196|IDF 128-2. Milk - definition and evaluation of the overall accuracy of alternative methods of milk analysis - part 2: calibration and quality control in the dairy laboratory. 2009c.

MILK and milk products: guidance on sampling. Brussels: International Dairy Federation, Standard, 1995. 
OLIVEIRA, M.C.P.P. Espectrofotometria no infravermelho por metodologia FTIR (Fourier Transform Infrared): validação da análise do teor de ureia e de outros parâmetros de qualidade do leite. 2011. 70f. Dissertação (Mestrado em Medicina Veterinária) - Escola de Veterinária, Universidade Federal de Minas Gerais, Belo Horizonte, MG.
REZENDE, P.S.; CARMO, G.P.; ESTEVES, E.G. Avaliação do efeito do congelamento de amostras de leite na determinação do índice de refração do soro cúprico. Rev. Bras. Pesqui. Aliment., v.6, p.9$15,2015$.

ZAJÁC, P.; ZUBRICKÁ, S.; ČAPLA, J. et al. Effect of preservatives on milk composition determination. Int. Dairy J., v.61, p.239-244, 2016. 